\title{
Socioenvironmental Vulnerability to Climate Change: Conditions of Coastal Municipalities in Pará State
}

\author{
Marcos Ronielly da Silva Santos \\ Maria Isabel Vitorino \\ Luci Cajueiro Carneiro Pereira \\ Marcia Aparecida da Silva Pimentel \\ Ana Flávia Quintão
}

I Federal University of Pará, Belém City, Pará State, Brazil.

" Federal University of Pará, Belém City, Pará State, Brazil.

III Federal University of Pará, Bragança City, Pará State, Brazil.

D IV Federal University of Pará, Belém City, Pará State, Brazil.

${ }^{v}$ Minas Gerais State School of Public Health, Belo Horizonte City, Minas Gerais State, Brazil.

\begin{abstract}
The aim of the current study is to analyze the vulnerability of coastal municipalities in Pará State, based on the integration of socioeconomic, epidemiological and climatic indicators. Data were combined to climate scenarios such as Representative Concentration Pathway (RCP) 4.5 and 8.5, depending on the Municipal Vulnerability Index (MVI). Results have shown that the Sensitivity (SeI) and Sociodemographic (SdI) Indices had strong influence on the current vulnerability of the investigated municipalities. The association between current vulnerability index and future climate change projections has shown that municipalities located in Marajó Island region are the most vulnerable ones - to the West of the study site, where MVI ranged from 1 (in Afuá) to 0.55 (in Soure), for scenarios 4.5 and 8.5, respectively. The current results can contribute to the effective adoption of public policies focused on prioritizing the most vulnerable municipalities and on preparing them to deal with adverse aspects of climate change.
\end{abstract}

Keywords: Climate; Risks; Socioenvironment; Costal Region; Pará State.

São Paulo. Vol. 24, 2021

Original Article

DOI: http://dx.doi.org/10.1590/1809-4422asoc20200167r1vu2021L3AO 


\section{Introduction}

Coastal regions are particularly vulnerable to climate changes, since they are directly influenced by oceanic, atmospheric and continental processes (NEVES; MUEHE, 2010). The Intergovernmental Panel on Climate Change (IPCC, 2014) has confirmed that coastal regions are the areas most affected by climate change, if one takes into consideration the mean increase in ocean levels and the intensity of extreme climatic events. Brazilian coastal cities such as Florianópolis, Rio de Janeiro, Salvador, João Pessoa, Natal and Belém are expected to register higher temperatures with intense heat peaks, as well as to experience high tides, as well as undertow and heavy rainfall events (PBMC, 2016).

The Brazilian coastal zone presents large occupied territorial extensions. Nowadays, 463 municipalities cover the first $100 \mathrm{~km}$ of the coast and comprise more than 17.4 million households or approximately $30 \%$ of the population, which corresponds to 50.7 million inhabitants (IBGE, 2019). These municipalities and their populations are exposed to coastal environmental risks caused by climate change in Brazil. The Amazon coastal region is one of the largest human concentration areas (RODRIGUES; CASTRO, 2013). It comprises three metropolitan regions: Macapá (AP), Belém (PA) and São Luís (MA), and concentrates approximately 3 million inhabitants (IBGE, 2019). The regions is featured by fast and disordered urbanization process, and it leads to severe socio-environmental issues such as territorial occupation in risk areas, deforestation, overfishing, and contamination of water tables, rivers and estuaries (PEREIRA et al., 2009).

Based on this interpretation, climate change gains greater visibility, since it has deep social, economic, political and environmental implications (OJIMA; MARANDOLA JR SANTOS, 2013; SANTOS et al., 2017). The main environmental and social consequences of climate change lie on increased temperature, sea level rise, extreme rainfall events, and intensified hydrological cycles with higher incidence of drought and flood (CONTI, 2005; BESSAT, 2015). These changes in global climate will directly influence the lives of different populations, have different impacts on them and affect the degree of and/or individuals' perception about socio-environmental vulnerability (RIBEIRO, 2010; IPCC, 2014; SANTOS et al., 2017).

Socio-environmental vulnerability has different approaches and represents a complex and multidimensional phenomenon, since it requires a combination of factors to determine the degree to which a given group is put at risk by a discrete and identifiable event in nature and/or society (MAIOR; CÂNDIDO, 2014). Socio-environmental vulnerability is herein understood as "a set of characteristics of a person or group, in terms of their capacity to anticipate, cope with, resist and recover from the impact of a hazard" (BLAIKIE et al., 2005; O'BRIEN et al., 2011).

The number of scientific studies about socio-environmental vulnerability has increased in recent decades; thus, it is necessary having specific knowledge about likely socioenvironmental vulnerability modulators at different territorial scales - global, regional and local (ZANELLA et al., 2013; SCHUMANN; MOURA, 2015; MAVROMATIDI et al., 2018; GUPTA et al., 2020). This topic is mainly associated with society's adaptation to climate change; this adaptation process is necessary due to high incidence of extreme 
events, mainly of rainfall events capable of directly affecting humans at collective level (TIBÚRCIO; CORRÊA, 2012; SANTOS et al., 2017).

The project called "Construction of Indicators for Municipal Assessments of Human Vulnerability to Climate Change in Brazil” was launched in 2014, in order to develop a methodology capable of assessing population's vulnerability to climate change, based on indicators used to measure and compare the reality of the investigated municipalities in some states countrywide (CONFALONIERI et al., 2016; QUINTÃO et al., 2017). Recent studies were published in Amazonas, Espírito Santos and Maranhão states (MENEZES et al., 2018; SANTOS et al., 2019; VOMMARO et al., 2020) as results of the aforementioned project. They adopted the Climate Vulnerability System's (Sisvuclima) methodology and software. This method enables spatializing indicators and better understanding the most vulnerable local aspects to make climate adaptation strategies, actions and resources' planning easier (FIOCRUZ, 2016).

Thus, it is essential conducting research focused on correlating different methodologies in order to measure socio-environmental vulnerability at municipal level, by linking the climatic component to the social one, both with interdisciplinary character, mainly in coastal cities and regions lacking research on this topic (IWAMA et al., 2014; ZANETTI et al., 2016). Santos et al. (2017) investigated socio-environmental vulnerability in a metropolitan Amazon region, based on indices and indicators, which were used to explain the important role played by climate index in defining local vulnerability. Several scholars, such as Souza-Filho (2001), Szlafsztein and Sterr (2007, 2010), and Espírito-Santo and Szlafsztein (2016), have developed research and methodologies based on indices and indicators used to measure the degree of environmental and social vulnerability in different municipalities in the coastal zone of Pará State; however, their local surveys did not address climate change scenarios, as per the project by Confalonieri et al. (2016).

The contribution of this research lies on showing that the incidence of extreme weather events, identified through climatic scenarios, can increase vulnerability indices in their multiple facets and leave populations living in coastal municipalities more exposed to socio-environmental risks. The ongoing climate change is an extremely severe global issue that has impact on all spheres of human life - from public policy to food security, which is a particularly critical issue if one analyzes it based on the socio-environmental perspective. Based on such a scenario, the aim of the current study was to feature the socio-environmental vulnerability of coastal municipalities in Pará State, based on the Municipal Vulnerability Index (MVI) and on climate change scenarios. The concept of vulnerability was herein adopted based on features such as exposure, sensitivity and adaptive capacity, and on places where the socio-ecological system contributes to make people and territories more or lesser vulnerable. 


\section{Materials and Methods}

\section{Study site featuring}

The current research comprised all 30 coastal municipalities in Pará State (MMA, 2020), which are located in the Eastern portion of the coastal region of the Amazon and belong to Northeastern Pará and Marajó mesoregions (Figure 1A). The study site has a territorial extension of approximately $52,520 \mathrm{~km}^{2}$ and estimated population of $3,037,179$ inhabitants (IBGE, 2019). The coastal region of Pará State concentrates 36\% of ... the population in approximately $5 \%$ of the state's territory, most municipalities present lowto-medium Human Development Index (HDI) indicator (UNDP, 2019) (Figure 1B). The investigated municipalities have different historical backgrounds, population sizes and economic weight; these conditions must be taken into account at the time to analyze and interpret the analysis results. According to (ALMEIDA; JARDIM, 2018), socioeconomic and environmental changes that took place on the coast of Northeastern Pará State resulted from public policies focused on socioeconomic development. The vegetation in the region presents pioneer formations, dense rain forest, mangrove areas; however, there have been changes in vegetation index in the last decades, as shown in the NDVI image (Figure 1C) (IBGE, 2012).

The climate in the region is classified as humid equatorial and presents two welldefined seasons: the rainy season takes places from December to May, and the lesser rainy season, from June to November (AMANAJÁS; BRAGA, 2012). The rainy regime presents rainfall volume ranging from $125 \mathrm{~mm}$ to $400 \mathrm{~mm} / \mathrm{month}$, which is generated by the Intertropical (ITCZ) and South Atlantic Convergence (SACZ) Zones; these zones are the main rainfall-related meteorological systems - mean temperature is $23^{\circ} \mathrm{C}$ and relative air humidity reaches $85 \%$. The lesser rainy regime presents rainfall accumulation ranging from $30 \mathrm{~mm}$ to $150 \mathrm{~mm} / \mathrm{month}$, which is caused by the action of convective clusters, instability lines and local systems - mean temperature is $26^{\circ} \mathrm{C}$ and relative air humidity reaches approximately 70\% (SILVA SANTOS et al., 2016; SOUZA et al., 2017).

The study site is inserted in the coastal geomorphological unit of mangroves, rivers and plateaus in Pará State (IBGE, 2009); the unit is formed by a set of depositional features of fluvial, marine and lake origin, and it also comprises a series of islands, bays and channels, where the flat relief with low amplitude and less than $100 \mathrm{~m}$ elevation stands out (DANTAS et al., 2014). Another peculiar feature of the study site lies on the macrotidal regime, which presents maximum height of $6 \mathrm{~m}$ and extensive mangrove area (PEREIRA et al., 2009). 
Figure 1 - (A) Study site location in South America. (B) study site with Human Development Index (HDI) data. (C) study site with Normalized Difference Vegetation Index (NDVI) from 1998 to 2018

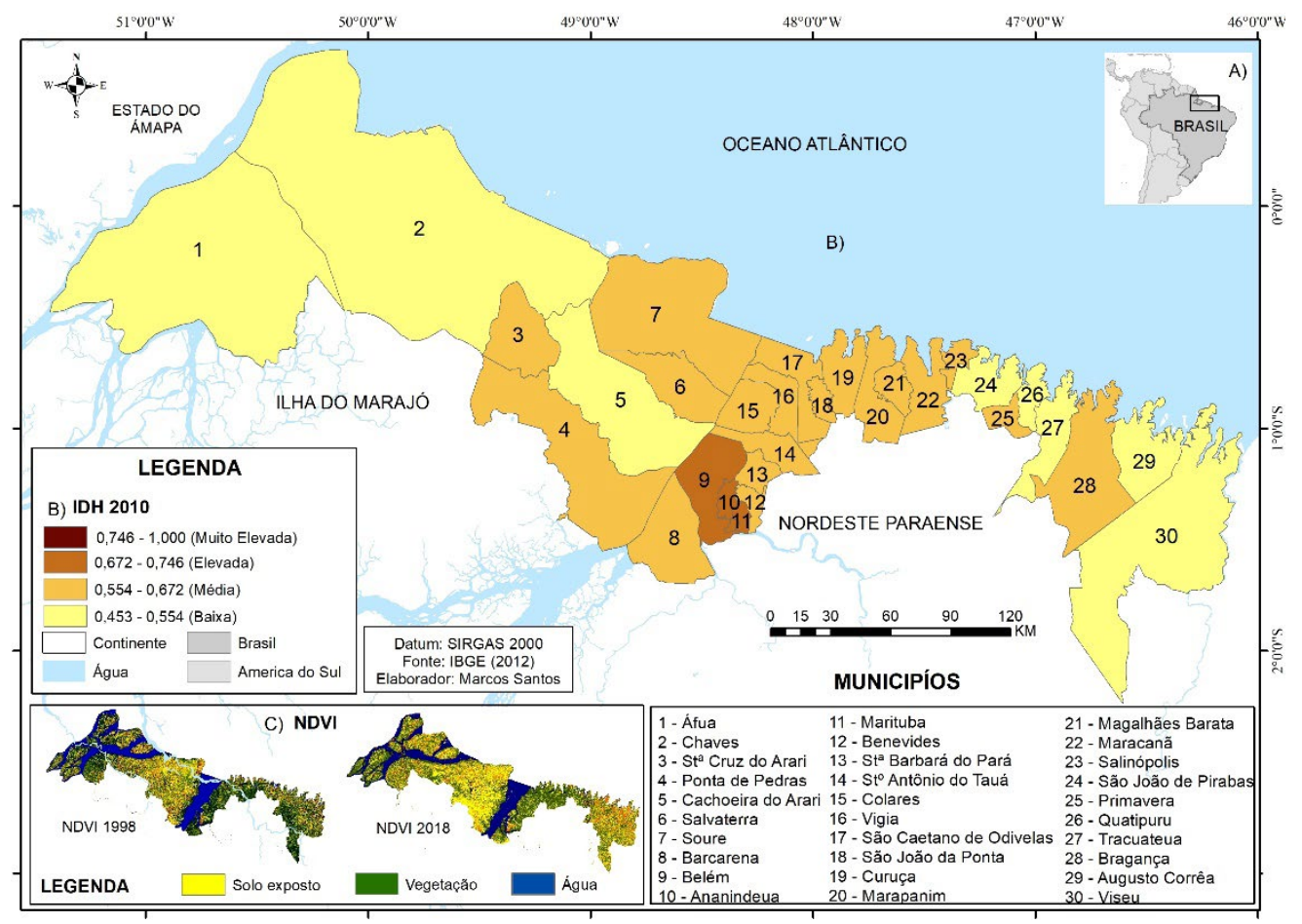

Source: Elaborated by the author, 2021.

\section{Conceptual model of the Municipal Vulnerability Index - MVI}

The municipal vulnerability index (MVI) applied in the current study derived from previous studies carried out in other Brazilian locations (BARATA et al., 2011; CONFALONIERI et al., 2015, 2016; QUINTÃO et al., 2017; MENEZES et al., 2018; SANTOS et al., 2019; VOMMARO et al., 2020); it was adapted based on conceptual models of Human Vulnerability Index presented by Quintão et al. (2017) and on the MVI model by Vommaro et al. (2020). In conceptual terms, MVI takes into consideration the multiple human, social, environmental and economic development processes taking place in different municipalities and contributing to their vulnerability profile before climate change. Therefore, based on Adger (2006) and Quintão et al. (2017), this profile can be featured according to three basic overall vulnerability dimensions (exposure, sensitivity and adaptive capacity), in association with the climate change scenarios presented in the current study.

Exposure is featured by the nature and intensity of the environmental stress coastal municipalities are exposed to, namely: biophysical - vegetation cover area, coastline 
extension; and climate - extreme rainfall and temperature events) or, yet, socio-political - analyzed based on a given system (the territory). The features of this stress comprise its size, frequency and extension of the risk area. Sensitivity investigates the extent to which a system can be damaged or affected by (climate) disturbances, as determined by the system's intrinsic susceptibilities. The current research took into consideration water-associated endemics and socioeconomic processes susceptible to climatic anomalies.

Adaptive capacity is enabled by systems' ability to make or introduce changes in order to accommodate environmental and political stresses, as well as on systems' ability to better manage any consequences, thus expanding the range of variability they can handle. The current study took into consideration the public and basic health services attending the population in adverse climate cases. Thus, it considers that climate change acts as external influence capable of changing the vulnerability profile in each municipality and of making resident populations more vulnerable to social and environmental impacts.

\section{Indices and sub-indices}

The method used in the current research combines synthetic indices capable of providing comparative measurements of vulnerability in different aspects and their association with extreme climate events (Chart 1 ). The information is statistically analyzed for each municipality, by taking into account the incidence of population size bigger than 10,000 inhabitants in order to generate the Municipal Vulnerability Index. This index is calculated by taking into consideration climate change in the two representative concentration pathways (RCPs) 4.5 and 8.5. Data selection was based on: 1) data availability, 2) the conceptual framework established by previous research conducted in the Amazon region (MENEZES et al., 2018; VOMMARO et al., 2020), and 3) scientific literature about vulnerability quantification and assessment (CONFALONIERI et al., 2015, 2016; QUINTÃO et al., 2017).

The General Vulnerability Index (GVI) represents the current conditions of coastal municipalities in Pará State and it is associated with exposure (ExI), sensitivity (SeI) and adaptive capacity (ACI) sub-indices. Climate Index (CI) was built based on climatic anomalies generated by the absolute difference between projected climate (2020-2050) and baseline climatological observations (1961-1990).

The herein used climatic variables deriving from the output model comprised mean annual temperatures (TP2M) in degrees Celsius and total rainfall rate (RAIN) in millimeters provided by the ETA/HadGEM2 model for the period from 2020 to 2050 (CHOU et al., 2014, CPTEC, 2019). Scenarios referring to RCPs 4.5 and 8.5, which were used by the Climate Panel (IPCC, 2014), were adopted in the current study. RCP 4.5 corresponds to the stabilization of greenhouse gas (GHG) emissions by 2100 (best case scenario), whereas RCP 8.5 corresponds to increased GHG emissions by 2100 (worst case scenario). 


\section{Chart 1 - Variables used in the current study.}

\begin{tabular}{|c|c|c|c|}
\hline \multicolumn{4}{|c|}{ Municipal Vulnerability Index (MVI) } \\
\hline \multicolumn{4}{|c|}{ General Vulnerability Index (GVI) } \\
\hline \multirow{3}{*}{$\begin{array}{l}\text { Exposure Index } \\
\text { ExI }=\end{array}$} & $\begin{array}{l}\text { Vegetation Cover Index (VCI) } \\
\text { VCI }=\end{array}$ & $\begin{array}{l}\text { (i) Native vegetation cover (absolute area) } \\
\text { (ii) Native vegetation cover (Percentage) }\end{array}$ & $\begin{array}{l}\text { Mapbiomes. } \\
\text { Period: } 1998 \text { to }\end{array}$ \\
\hline & $\begin{array}{l}\text { Natural Disaster Index (NDI) } \\
\text { NDI }=\end{array}$ & $\begin{array}{l}\text { (i) Natural Disasters (percentage) } \\
\text { (ii) Extreme rainfall events (percentage) }\end{array}$ & $\begin{array}{l}\text { Brazilian Atlas of } \\
\text { Natural Disasters. }\end{array}$ \\
\hline & $\begin{array}{l}\text { Coastal Exposure Index (CEI) } \\
\text { CEI }=\end{array}$ & $\begin{array}{l}\text { (i) Coastline (CL) (Kilometers) } \\
\text { (ii) Distance from the Coast to the Urban Center }\end{array}$ & $\begin{array}{l}\text { Author, (2019) } \\
\text { IBGE cartogra- }\end{array}$ \\
\hline \multirow{2}{*}{$\begin{array}{l}\text { Sensitivity Index } \\
(\mathrm{SeI}) \\
\mathrm{SeI}=\end{array}$} & $\begin{array}{l}\text { Endemic Disease Index (EDI) } \\
\text { EDI }=\end{array}$ & $\begin{array}{l}\text { (i) Endemic diseases (incidence) } \\
\text { (ii) Endemic disease (proportion) }\end{array}$ & $\begin{array}{l}\text { Pará Department } \\
\text { of Health (DA- } \\
\text { TASUS / SESPA) }\end{array}$ \\
\hline & $\begin{array}{l}\text { Sociodemographic Index (SdI) } \\
\text { SdI = }\end{array}$ & $\begin{array}{l}\text { (i) Population's schooling (incomplete elementary scho- } \\
\text { ol and illiterate at } 25 \text {-year-old or older (proportion) } \\
\text { (ii) Mortality of children younger than } 1 \text { year (Rate) }\end{array}$ & $\begin{array}{l}\text { Brazilian Institute } \\
\text { of Geography and } \\
\text { Statistics. } 2010\end{array}$ \\
\hline \multirow{2}{*}{$\begin{array}{l}\text { Adaptive Capaci- } \\
\text { ty Index }(\mathrm{ACI}) \\
\mathrm{ACI}=\end{array}$} & $\begin{array}{l}\text { FIRJAN Municipal Development } \\
\text { Index - FMDI }\end{array}$ & (i) FMDI Result & $\begin{array}{l}\text { Industry Federa- } \\
\text { tion, IDHM, } 2010\end{array}$ \\
\hline & $\begin{array}{l}\text { Primary Care Coverage Indicator } \\
\text { - PCCI }\end{array}$ & (i) Population covered by primary health care & $\begin{array}{l}\text { Ministry of Heal- } \\
\text { th. (DATASUS) }\end{array}$ \\
\hline \multicolumn{2}{|l|}{$\begin{array}{l}\text { Climate Index }(\mathrm{CI}) \\
\mathrm{CI}=\end{array}$} & $\begin{array}{l}\text { (i) - Rainfall and temperature anomaly RCP } 4.5 \\
\text { (ii) Rainfall and temperature anomaly RCP } 8.5\end{array}$ & $\begin{array}{l}\text { Space Research } \\
\text { Institute (INPE) } \\
2019\end{array}$ \\
\hline
\end{tabular}


Municipal Vulnerability Index (MVI) corresponds to the association between GVI and the CI 4.5 or IC 8.5 obtained for each municipality; it synthetically represents the association between current vulnerability and future scenarios under climate change. Data composing the indicators and variables were extracted from governmental websites and are available (free of charge) on their specific webpages.

\section{Standardization and calculation}

Indices were calculated in three different steps: i) weight assignment, ii) arithmetic mean and standardization and iii) combination of indices. Variables were grouped per municipality in hierarchical cluster (WANG; SONG, 2011) and analyzed in SPSS software, based on the between-group linkage method and on the Euclidean distance interval. They were classified into five groups, whose weights ranged from 1 and 5, wherein: 1 represents the least vulnerable group and 5 represents the most vulnerable one. In the case of components such as Vegetable Cover Index (VCI), Distance from the Coast to the Urban Center (DCUC), Firjan Municipal Development Index (FMDI) and Primary Care Coverage Indicator (PCCI), this logic is reversed, since these components present elements capable of reducing the vulnerability of the population, i.e., the higher the values recorded for the variables, the lower the vulnerability; in these cases, the weights were attributed in an inverse way.

Subsequently, weights were aggregated through simple arithmetic mean in order to form the sub-indices. All sub-indices and indices were standardized in order to present the same range from 0 to 1 ( 0 represents the least vulnerable group and 1 , the most vulnerable group), through equation (1):

$$
\text { Is }=\frac{\text { ObsI }- \text { Minumum I }}{\text { Maximum I }- \text { Minimum I }}
$$

Wherein,

Is $=$ Standardized index

ObsI = Observed index (for each municipality)

Maximum I = highest value observed among the calculated indices

Minimum I = lowest value observed among the calculated indices

All calculation procedures were performed in Excel software. It is essential highlighting that the generated index is comparative, as well as that its score 'zero' does not indicate lack of vulnerability and score 1 does not mean total vulnerability. According to (SANTOS et al., 2017), scores indicate the degree of vulnerability of a given municipality in comparison to other municipalities in the study site.

\section{Data spatialization}

Indices were mapped by taking into consideration municipal cartographic bases 
according to IBGE (2019). They were illustrated according to the vulnerability scale classification methodology presented by Freitas and Cunha (2013), according to which, index values are aggregated into five categories, namely: extremely low $(0-0.19)$, low $(0.20-0.39)$, medium $(0.40-0.59)$, high $(0.60-0.79)$ and extremely high $(0.80-1)$. This classification was attributed to the remote sensing software (QGis 2.18.14) at the time to plot the thematic maps.

\section{Results}

Table 1 presents synthetic index values recorded for each analyzed dimension, as well as standardized values of each indicator or variable composing the referred indices.

Table 1 - Vulnerability indices per municipalities and standardized indicators

\begin{tabular}{|c|c|c|c|c|c|c|c|c|c|c|c|c|c|c|c|}
\hline Municipality & $\mathrm{VCI}$ & NDI & CEI & ExI & EDI & SdI & SeI & FMDI & PCCI & ACI & GVI & $\begin{array}{l}\mathrm{CI} \\
4.5\end{array}$ & $\begin{array}{l}\mathrm{CI} \\
8.5\end{array}$ & $\begin{array}{c}\text { MVI } \\
4.5\end{array}$ & $\begin{array}{l}\text { MVI } \\
8.5\end{array}$ \\
\hline Afuá & 0.14 & 0.16 & 1.00 & 0.36 & 0.14 & 0.92 & 0.86 & 1 & 1 & 1.00 & 1.00 & 1.0 & 1 & 1.00 & 1.00 \\
\hline Ananindeua & 0.57 & 0.33 & 0.43 & 0.38 & 0.73 & 0.08 & 0.55 & 0.25 & 0.25 & 0.14 & 0.47 & 0.8 & 0.4 & 0.59 & 0.34 \\
\hline $\begin{array}{l}\text { Augusto } \\
\text { Corrêa }\end{array}$ & 0.43 & 0.83 & 0.57 & 0.69 & 0.40 & 0.77 & 0.99 & 0.5 & 0 & 0.14 & 0.82 & 0.0 & 0 & 0.34 & 0.31 \\
\hline Barcarena & 0.57 & 0.33 & 0.57 & 0.46 & 0.26 & 0.23 & 0.16 & 0 & 0.25 & 0.00 & 0.27 & 0.8 & 0.4 & 0.48 & 0.22 \\
\hline Belém & 0.71 & 0 & 0.71 & 0.43 & 1.00 & 0.00 & 0.78 & 0 & 0.75 & 0.29 & 0.67 & 0.6 & 0.4 & 0.59 & 0.45 \\
\hline Benevides & 0.43 & 0.16 & 0.14 & 0.00 & 0.14 & 0.23 & 0.02 & 0.25 & 0 & 0.00 & 0.00 & 0.8 & 0.4 & 0.33 & 0.06 \\
\hline Bragança & 0.43 & 1 & 0.57 & 0.79 & 0.66 & 0.46 & 0.92 & 0.5 & 0 & 0.14 & 0.83 & 0.4 & 0 & 0.57 & 0.31 \\
\hline $\begin{array}{l}\text { Cachoeira do } \\
\text { Arari }\end{array}$ & 0.86 & 0.66 & 0.29 & 0.67 & 0.00 & 0.46 & 0.13 & 0.75 & 1 & 0.86 & 0.74 & 0.6 & 0.6 & 0.63 & 0.61 \\
\hline Chaves & 0.00 & 0.66 & 1.00 & 0.67 & 0.00 & 1.00 & 0.78 & 0.5 & 0.75 & 0.57 & 0.91 & 0.8 & 1 & 0.84 & 0.95 \\
\hline Colares & 0.57 & 0.33 & 0.71 & 0.55 & 0.00 & 0.54 & 0.22 & 0.25 & 0 & 0.00 & 0.34 & 0.4 & 0.4 & 0.30 & 0.26 \\
\hline Curuçá & 0.43 & 0.5 & 0.57 & 0.48 & 0.00 & 0.54 & 0.22 & 0.75 & 0.25 & 0.43 & 0.50 & 0.8 & 0.6 & 0.61 & 0.47 \\
\hline $\begin{array}{c}\text { Magalhães } \\
\text { Barata }\end{array}$ & 0.43 & 0.33 & 0.43 & 0.29 & 0.00 & 0.54 & 0.22 & 0.5 & 0 & 0.14 & 0.28 & 0.4 & 0.6 & 0.27 & 0.34 \\
\hline Maracanã & 0.43 & 0.33 & 0.57 & 0.38 & 0.07 & 0.54 & 0.30 & 1 & 0 & 0.43 & 0.49 & 0.2 & 0.2 & 0.27 & 0.23 \\
\hline Marapanim & 0.43 & 0.66 & 0.43 & 0.49 & 0.15 & 0.46 & 0.31 & 0.5 & 0.25 & 0.29 & 0.48 & 0.8 & 0.6 & 0.60 & 0.46 \\
\hline Marituba & 0.43 & 0.16 & 0.29 & 0.10 & 0.59 & 0.15 & 0.47 & 0.25 & 0.5 & 0.29 & 0.38 & 0.8 & 0.4 & 0.54 & 0.28 \\
\hline $\begin{array}{l}\text { Ponta de } \\
\text { Pedras }\end{array}$ & 0.43 & 0.16 & 0.57 & 0.27 & 0.15 & 0.46 & 0.31 & 0.5 & 0.5 & 0.43 & 0.45 & 0.6 & 0.4 & 0.47 & 0.32 \\
\hline Primavera & 0.43 & 0.33 & 0.29 & 0.20 & 0.00 & 0.39 & 0.03 & 0.25 & 0 & 0.00 & 0.09 & 0.2 & 0.2 & 0.05 & 0 \\
\hline Quatipuru & 0.43 & 0.33 & 0.43 & 0.29 & 0.38 & 0.62 & 0.77 & 0.5 & 0.5 & 0.43 & 0.67 & 0.2 & 0.2 & 0.37 & 0.34 \\
\hline Salinópolis & 0.43 & 0.33 & 0.71 & 0.47 & 0.13 & 0.23 & 0.00 & 0.25 & 0 & 0.00 & 0.20 & 0.0 & 0.2 & 0.00 & 0.06 \\
\hline Salvaterra & 0.71 & 0.5 & 0.71 & 0.74 & 0.00 & 0.46 & 0.13 & 0.5 & 0.5 & 0.43 & 0.58 & 0.0 & 0.4 & 0.21 & 0.40 \\
\hline $\begin{array}{l}\text { Santa Bárbara } \\
\text { do Pará }\end{array}$ & 0.43 & 0 & 0.29 & 0.00 & 0.07 & 0.39 & 0.11 & 0.25 & 0 & 0.00 & 0.04 & 0.6 & 0.4 & 0.24 & 0.08 \\
\hline $\begin{array}{c}\text { Santa Cruz do } \\
\text { Arari }\end{array}$ & 1.00 & 0.5 & 0.00 & 0.48 & 0.30 & 0.54 & 0.59 & 0.5 & 0 & 0.14 & 0.54 & 0.6 & 0.6 & 0.52 & 0.49 \\
\hline $\begin{array}{l}\text { Santo Antônio } \\
\text { do Tauá }\end{array}$ & 0.57 & 0.66 & 0.29 & 0.49 & 0.28 & 0.39 & 0.37 & 0.5 & 0 & 0.14 & 0.44 & 0.6 & 0.4 & 0.47 & 0.32 \\
\hline $\begin{array}{l}\text { São Caetano de } \\
\text { Odivelas }\end{array}$ & 0.43 & 0.33 & 0.43 & 0.29 & 0.00 & 0.46 & 0.13 & 0.75 & 0 & 0.29 & 0.31 & 1.0 & 0.4 & 0.62 & 0.24 \\
\hline $\begin{array}{l}\text { São João da } \\
\text { Ponta }\end{array}$ & 0.43 & 0.5 & 0.29 & 0.31 & 0.00 & 0.54 & 0.22 & 0.25 & 0 & 0.00 & 0.23 & 0.2 & 0.4 & 0.13 & 0.19 \\
\hline
\end{tabular}




\begin{tabular}{c|c|c|c|c|c|c|c|c|c|c|c|c|c|c|c}
\hline $\begin{array}{c}\text { Sáo João de } \\
\text { Pirabas }\end{array}$ & 0.43 & 0.33 & 0.71 & 0.47 & 0.13 & 0.62 & 0.47 & 0.5 & 0 & 0.14 & 0.48 & 0.2 & 0 & 0.27 & 0.11 \\
\hline Soure & 1.00 & 0.33 & 1.00 & 0.99 & 0.26 & 0.46 & 0.44 & 0.5 & 0.5 & 0.43 & 0.84 & 0.4 & 0.4 & 0.58 & 0.55 \\
\hline Tracuateua & 0.57 & 0.33 & 0.29 & 0.29 & 0.29 & 0.62 & 0.67 & 1 & 0 & 0.43 & 0.62 & 0.0 & 0 & 0.23 & 0.19 \\
\hline Vigia & 0.43 & 0.5 & 0.43 & 0.39 & 0.25 & 0.46 & 0.43 & 0.75 & 0.5 & 0.57 & 0.62 & 0.4 & 0.4 & 0.46 & 0.42 \\
\hline Viseu & 0.29 & 0.33 & 0.57 & 0.29 & 0.29 & 0.77 & 0.86 & 0.5 & 0.5 & 0.43 & 0.71 & 0.0 & 0 & 0.28 & 0.24 \\
\hline
\end{tabular}

Source: Elaborated by the author, 2021.

\section{General Vulnerability Index (GVI) and Coastal Exposure Sub-Index (CEI)}

The General Vulnerability Index (GVI) results from the exposure, sensitivity and adaptive capacity sub-indices observed for the coastal region of Pará State. The Exposure Index (ExI) has shown high and extremely high vulnerability $(0.67>0.99)$ in municipalities such as Soure, Bragança, Salvaterra, Augusto Corrêa and Cachoeira do Arari (Figure $2 A)$. Vegetation cover indicators $(0.71>1)$ and coastal exposure $(0.71>1)$ in Soure and Salvaterra have featured these municipalities as presenting high and extremely high vulnerability, respectively. Bragança and Augusto Corrêa presented high vulnerability associated with natural disaster indicators, which recorded the respective values $(0.83>$ $1)$. The vegetation cover indicator $(0.84)$ recorded for Cachoeira do Arari was associated with the high vulnerability of the municipality (Figure 2A).

Municipalities such as Augusto Corrêa, Bragança, Afuá, Viseu and Belém recorded the highest Sensitivity Index (SeI) values, which corresponded to high and extremely high vulnerability $(0.78>0.99)$ (Figure $2 \mathrm{~B})$. Sociodemographic index indicators in municipalities such as Augusto Corrêa (0.77), Afuá (0.92) and Viseu (0.77) were the mostly responsible for increasing their vulnerability. They were mainly associated with the expressive number of people with inactive economy and illiterate individuals. The highest values recorded for endemic disease indices were observed for Bragança (0.66), based on data about dengue; and for Belém (1), based on high values recorded for leptospirosis and schistosomiasis - this outcome has featured the higher vulnerability of these municipalities (Figure 2B).

The Adaptive Capacity Index (ACI) - which presents values recorded for the FIRJAN Municipal Development Index (FMDI) and Primary Care Coverage Indicator (PCCI) - has indicated the highest values $(0.43>1)$ in municipalities such as Afuá, Cachoeira do Arari, Chaves, Vigia and Curuçá, which corresponded to medium to extremely high vulnerability (Figure 2C). Afuá recorded the highest values for both indices (1) and it showed that this municipality was the least likely to present adaptive capacity. Cachoeira do Arari and Chaves presented the highest PCCI $(0.75>1)$, whereas Vigia and Curuçá recorded the highest FMDI values (0.75, both municipalities) (Figure 2C).

General Vulnerability Index (GVI) has shown extremely high vulnerability $(0.82$ $>1$ ) in municipalities such as Afuá, Chaves, Soure, Bragança and Augusto Corrêa (Figure 2D). Afuá recorded the highest adaptive capacity index (1). On the other hand, municipalities such as Chaves, Bragança and Augusto Corrêa presented extremely high vulnerability associated with sensitivity index values of $0.78-0.92$ and 0.99 , respectively. The exposure index (0.99) featured the vulnerability of Soure (Figure 2D). 
Figure 2 - Map showing: (A) Exposure Index, (B) Sensitivity Index, (C) Adaptive Capacity Index, (D) General Vulnerability Index, (E) Coastal Extension Weights, (F) Weight of Distance from Coast to Urban Center, (G) Coastal Exposure Index
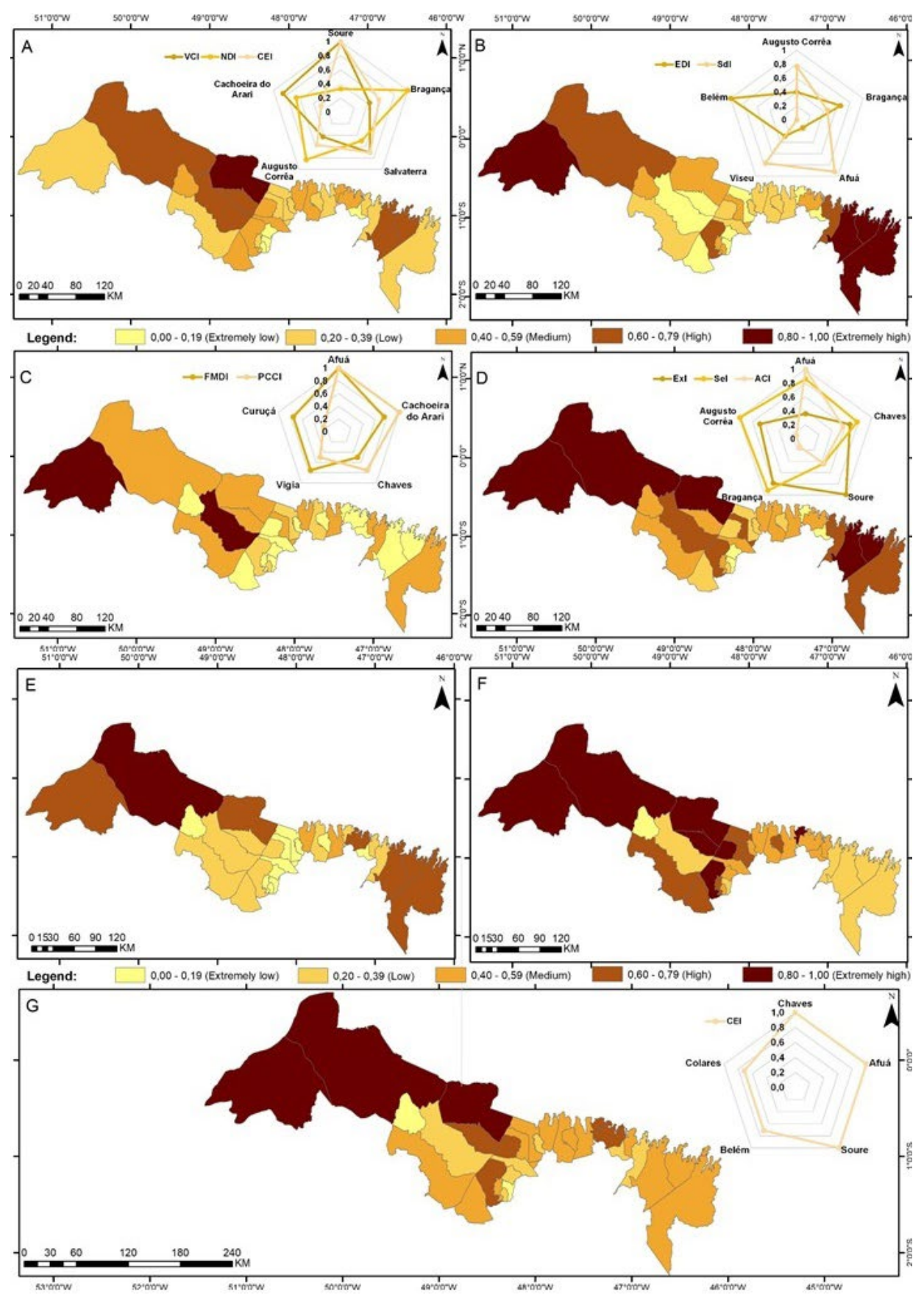

Source: Elaborated by the author, 2021. 
The coastal extension analysis has shown high vulnerability in the municipality of Chaves (weight 5), which presented coastline extension $>283.87 \mathrm{~km}$. Municipalities such as Afuá, Soure, Augusto Corrêa, Bragança and Viseu recorded weight 4 and presented coastline extensions ranging from $104 \mathrm{~km}$ to $127 \mathrm{~km}$. (Figure 2E). On the other hand, municipalities such as Afuá, Belém, Chaves, Colares, Salinópolis, Salvaterra and Soure recorded weight 5 for distance between coastline and urban center, and it corresponded to high vulnerability. Their values were lower than $0 \mathrm{~km}$, which means that their urban settlements are susceptible to increased sea level and flood events (Figure 2F).

Three municipalities in Marajó Island (Chaves, Afuá and Soure) were the most vulnerable to sea level rise. They recorded CEI value equal to 1 , and it indicated extremely high vulnerability. These municipalities presented the longest coastal stretches and the shortest distances from coastline to housing and urban centers. Municipalities such as Belém, Colares, Salinópolis and Salvaterra recorded CEI values $>0.71$, which corresponded to high vulnerability (Figure 2G).

\section{Climate Index (CI) and Municipal Vulnerability Index (MVI)}

Climate Index (CI) resulted from rainfall (Arain) and temperature (Atemp) anomalies observed in RCP scenarios 4.5 and 8.5. Based on CI analysis in scenario 4.5, municipalities such as Afuá, São Caetano de Odivelas, Ananindeua, Barcarena and Benevides presented extremely high vulnerability $(0.8<1)$ (Figure $3 \mathrm{~A}$ ). Temperature anomalies with weights equal to 5 and 3 were mainly accountable for the high vulnerability observed in municipalities such as Afuá $\left(1.75^{\circ} \mathrm{C}\right)$, Ananindeua $\left(1.74^{\circ} \mathrm{C}\right)$, Barcarena $\left(1.78^{\circ} \mathrm{C}\right)$ and Benevides $\left(1.75^{\circ} \mathrm{C}\right)$. São Caetano de Odivelas recorded rainfall anomaly weight equal to 5 , which was the main responsible for the increased vulnerability - maximum rainfall values reached $1,208 \mathrm{~mm}$ (Figure $3 \mathrm{~A}$ ).

Climate Index (CI) observed for scenario 8.5 recorded medium to extremely high vulnerability $(0.6>1)$ for municipalities such as Afuá, Chaves, Cachoeira do Arari, Curuçá and Magalhães Barata (Figure 5B). Rainfall anomalies with weights equal to 5 and 4 were found in Chaves $(1,004 \mathrm{~mm})$, Curuçá $(806 \mathrm{~mm})$ and Magalhães Barata (791 $\mathrm{mm}$ ), which corresponded to high vulnerability. Afuá (2.26 $\mathrm{C}^{\circ}$ ) and Cachoeira do Arari $\left(2.12 \mathrm{C}^{\mathrm{o}}\right)$ recorded temperature anomaly weights equal to 5 and 4 , which corresponded to high vulnerability (Figure 3B).

Municipal Vulnerability Index (MVI) resulted from the general vulnerability (GVI) and climate (CI) indices observed in coastal municipalities of Pará State, for RCP scenarios 4.5 and 8.5. With respect to MVI in scenario 4.5 (Figure 3C), municipalities such as Afuá, Chaves, Cachoeira do Arari, São Caetano de Odivelas and Curuçá recorded medium to extremely high vulnerability $(0.61>1)$. On the other hand, GVI was the index accounting for increasing the vulnerability of municipalities such as Afuá, Chaves, Cachoeira do Arari, which recorded GVI values 1 - 0.91 - 0.74, respectively. CI was the determining factor in São Caetano de Odivelas and Curuçá, which recorded values 1 and 0.8 , respectively (Figure $3 \mathrm{C}$ ). 
With respect to MVI in scenario 8.5, municipalities such as Afuá, Chaves, Cachoeira do Arari, Soure and Santa Cruz do Arari recorded medium $(0.49>0.6)$ to extremely high $(0.8>1)$ vulnerability (Figure 3D). The municipality of Afuá recorded high GVI value (1) and CI 8.5. Municipalities such as Cachoeira do Arari and Soure recorded GVI values 0.74 and 0.84 , respectively; both values determined their vulnerability within this scenario. On the other hand, municipalities such as Chaves and Santa Cruz do Arari recorded medium and high vulnerability due to CI.8.5 values 0.6 and 1, respectively (Figure 3D).

Figure 3 - Map showing: (A) Climate Index 4.5, (B) Climate Index 8.5 (C) Municipal Vulnerability Index 4.5, and (D) Municipal Vulnerability Index 8.5

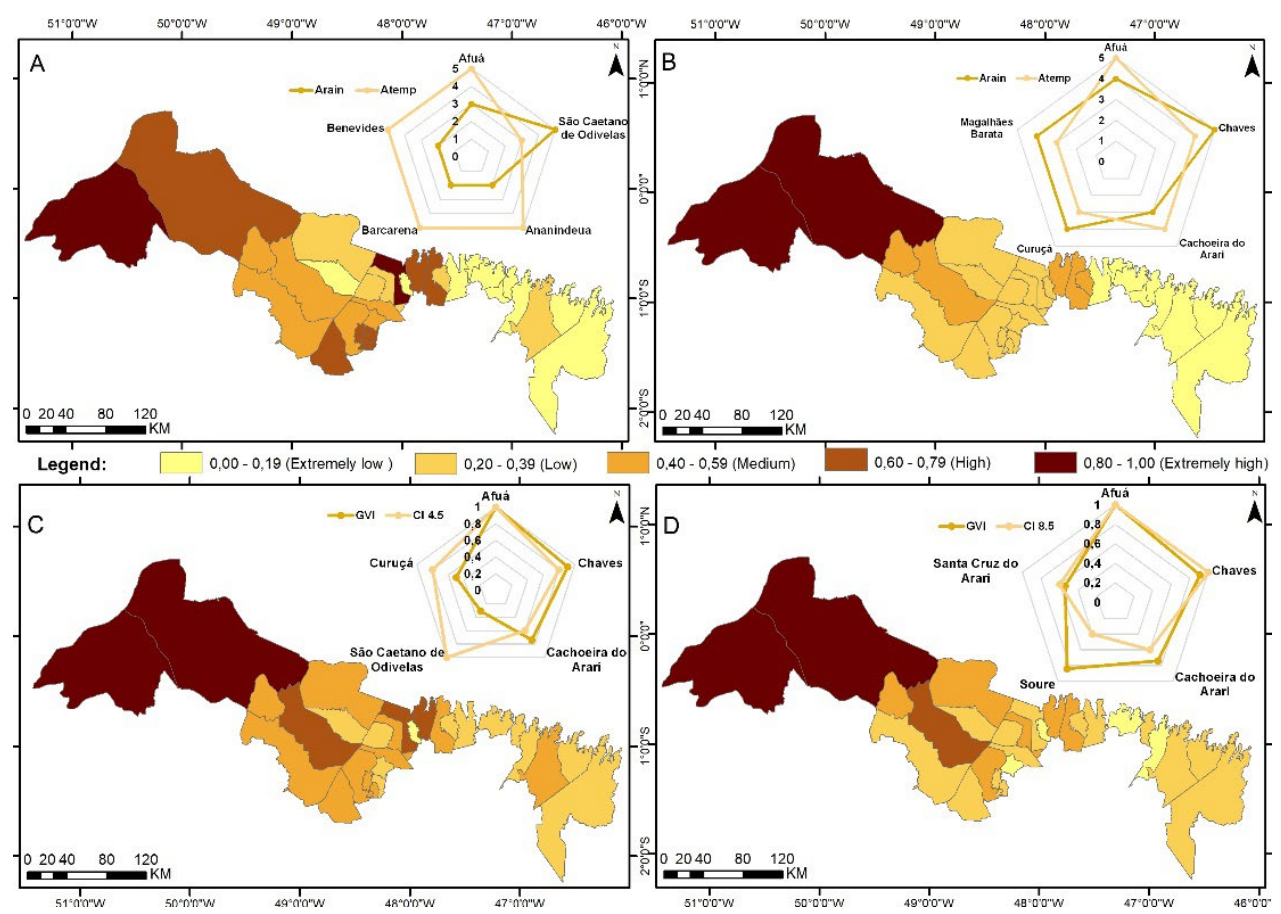

Source: Elaborated by the author, 2021.

\section{Discussion}

Methodologies such as MVI have been used by research bodies and governmental managers in several Brazilian cities, regions and states (CONFALONIERI et al., 2016; DARELA FILHO et al., 2016; DEBORTOLI et al., 2017) in order to provide the basis for decision-making as part of public policies addressing socio-environmental vulnerability based on the climate change perspective. However, the current study presented a new approach to the methodology, which was applied for the first time to coastal municipalities in Pará State and took into consideration variables adapted to the region. MVI combines 
two expected climate change scenarios and highlights the municipality with potential to be the most affected by climate change. MVI assessment contributes to climate adaptation strategies' planning and prioritization.

The current vulnerability state of coastal municipalities in Pará State was identified through MVI analyses, which evidenced that the investigated region is affected by natural pressures (extreme rainfall events and significant marine exposure), as indicated by the high MVI values recorded in the current study. An example of this phenomenon can be seen in factors such as increasing vegetation cover removal, increased number of natural disasters and climatic anomalies, as well as in social factors such as low schooling, increased number of endemic diseases (Leptospirosis and Dengue), and lack of public policies and services resulting in significant impacts on, and in the progressive degradation of, social and environmental systems in the coastal region. Studies conducted by Menezes et al. (2018), Santos et al. (2019) and Vommaro et al. (2020) have shown that several municipalities in different Brazilian states presented similar vulnerability reality, as seen through the high values observed for the aforementioned indicators, mainly in Amazonas, Espírito Santo and Maranhão states. Thus, these indicators can also be compared to the reality of coastal municipalities in Pará State.

With respect to the Exposure Index, the vegetation cover indicator was identified as determining factor for the high and extremely high vulnerability observed in municipalities of Marajó Island (Soure, Salvaterra and Cachoeira do Arari). Tourism, cattle and buffalo ranching, and plant extraction are the main economic activities in this region (SOUZA, 2009), a fact that may explain the increased local deforestation rates. Although these municipalities have large green areas, they are also large in territorial area, and it increases the weights recorded for this index. According to Santos et al. (2019), low vegetation cover rate is also an aggravating factor in the vulnerability of municipalities in Northern Espírito Santo State. Vegetation cover can help measuring vulnerability, since its removal and/or lack can lead to flooding, landslides and coastal erosion - in coastal regions (DEBORTOLI et al., 2017). It is one of the variables used as indicator in the equation presented by Leal Filho et al. (2018), which was adopted to compare coastal vulnerability indices between countries.

The sociodemographic aspect is considered an aggravating factor to municipal sensitivity, since socially marginalized populations (e.g., low-schooling/illiterate individuals, the ones living under inadequate sanitation conditions, and population with inactive economy) found in many coastal municipalities in Pará State (SILVA et al., 2018) have a hard time adapting to climate change (VOMMARO et al., 2020). Studies conducted by Menezes et al. (2018) and Vommaro et al. (2020) have shown that poverty index is the main sensitivity indicator accountable for increasing vulnerability in Amazonas and Maranhão states. Poverty index in the current study was attributed to the indicator 'economically-inactive population' and it recorded the highest values in municipalities such as Chaves, Colares, Viseu, Magalhães Barata and Augusto Corrêa.

The adaptive capacity index has shown mixed results, and it indicated that each municipality has different adaptation capacity and resilience formation features. Higher 
adaptation capacity was observed for the most populous municipalities located close to the Metropolitan Region of Belém (RMB) and in Northeastern Pará State (Belém, Barcarena, Salinópolis and Ananindeua). These municipalities tend to have better accessibility, infrastructure and more developed economy in comparison to the lesser populated municipalities, which are located further away from the metropolitan region of Belém and in Marajó Island (Afuá, Chaves, Soure and Salvaterra). The current study corroborates the findings by Pereira and Vieira (2016), who emphasized the important role played by institutional organizations, infrastructure and economic social capital formation in dealing with climate change.

Nowadays, the Metropolitan Region of Belém (RMB) occupies the $18^{\text {th }}$ position in the ranking of the best HDI among Brazilian metropolitan regions (HDI, 2019). Health services, education and the economy based on service supply are the main differential factors in Belém and Ananindeua, in comparison to other municipalities in the RMB, since they can help reducing social and human vulnerability in society (LIMA; MOYSÉS, 2009; PNUD, 2019). Studies conducted by MENEZES et al. (2018); SANTOS et al. (2019) and VOMMARO et al. (2020) adopted similar methodologies to investigate municipal vulnerability. Results have shown that the Adaptive Capacity Index was the bottleneck for local adaptation to climate change.

According to the analysis of climatic scenarios based on the interpretation of the herein observed anomalies, the estimates for both scenarios (4.5 and 8.5) pointed towards the trend of increased temperature (between $1^{\circ} \mathrm{C}$ and $3^{\circ} \mathrm{C}$ ) and reduced rainfall (between $5 \%$ and 20\%) rates in coastal municipalities (CHOU et al. 2014; CPTEC, 2019). These trends were similar to results recorded by NOBRE et al. (2007), ARAÚJO JÚNIOR et al. (2013) and COSTA et al. (2019) for other scales. With respect to scenario 4.5, municipalities in Northeastern Pará State (São Caetano de Odivelas, Ananindeua, Barcarena and Benevides) were the most vulnerable to rainfall and temperature anomalies. However, with respect to scenario 8.5, municipalities in Marajó Island (Afuá, Chaves and Cachoeira do Arari) will be the most affected by climate changes associated with temperature and rainfall rates. Based on this perspective, the current study has provided preliminary information at local level on socio-environmental vulnerability to climate change in coastal municipalities in Eastern Amazon.

Studies conducted by Szlafsztein (2003), and Szlafsztein and Sterr (2007) about vulnerability in coastal municipalities in Northeastern Pará State have indicated that Maracanã, Curuçá and Magalhães Barata presented high and extremely high vulnerability, based on socioeconomic indicators such as income, schooling and economy, as well as on natural indicators such as topography, vegetation cover and coastline, among others; these findings corroborate results in the current research. However, these studies did not investigate coastal municipalities in Marajó Island. Municipalities such as Afuá and Chaves recorded the highest vulnerability indices, mainly with regards to social aspects such as high population rate with low schooling; demographic aspects such as large number of households without basic sanitation; and health aspects such as large number of children who may not turn 1 -year old. These results are similar to the ones reported by 
Crispim et al. (2016) for Marajó region and to official data deriving from Brasil (2007).

\section{Conclusions}

The current study was a pioneering attempt to assess socio-environmental vulnerability aspects in coastal municipalities in Pará State, based on different climate change scenarios. The main collaborations of this research lied on developing a set of indicators adapted to the reality of coastal municipalities in Pará State and on mapping municipal vulnerability at local level, based on the climate change perspective. Results have indicated the first step towards reducing the vulnerability of coastal municipalities in Pará State and making the population more adaptive to climate impacts, based on the following measures: strengthening their sensitivity conditions by improving their living, health and income conditions, since the economically-inactive population rate and the mortality rate of children younger than 1 year are the factors mostly influencing the current vulnerability of the investigated municipalities.

The vulnerability of coastal municipalities in Pará State is mainly associated with exposure, sensitivity and adaptive capacity conditions. The investigated climatic scenarios of rainfall and temperature anomalies have indicated that climate change will intensify local vulnerability. MVI in scenario 4.5 has shown that municipalities in Northeastern Pará State - in the Eastern portion of the study site - will be more vulnerable to climate change. On the other hand, MVI in scenario 8.5 has shown that municipalities in Marajó Island region - in the Western portion of the study site - were more susceptible to vulnerability to climate change.

The applied methodology was based on the construction of vulnerability indices, based on cluster analysis, variable standardization and arithmetic mean. This methodology is widely used in vulnerability measurement surveys. Nowadays, software such as Sisvuclima are capable of optimizing the calculations presented in the current study, although they are not yet widely available for use. Software implementation - mainly among educational and research institutions - helps assessing vulnerability and developing adaptation propositions for Brazilian municipalities. Thus, it is necessary capillarizing the adopted software to different governance levels associated with climate change in Brazil.

Therefore, the present study primarily aimed at collaborating with the local literature on socio-environmental vulnerability based on the climate change perspective, by promoting the discussion about and expansion of the topic, as well as by encouraging future research focused on using and improving the herein proposed method. In addition, it sought to assist municipal governments by enabling the management and development of a database about the vulnerability of the current and future societies to climate change. And finally, it is worth emphasizing its applicability by public policy makers focused on preventing and minimizing socio-environmental vulnerability at local level. 


\section{References}

ADGER, W. N. Vulnerability. Global Environmental Change. v. 16, n. 3, p. 268-281, 2006.

ALMEIDA, A. F.; JARDIM, M. A. G. Mudanças socioeconômicas e ambientais resultantes das políticas públicas de desenvolvimento socioeconômico no litoral do Nordeste do Pará, Brasil. Desenvolvimento e Meio ambiente, v. 49, p.108-127, 2018.

AMANAJÁS, J.C.; BRAGA, C. C. Padrões espaço-temporais pluviométricos na Amazônia Oriental usando análise multivariada. Revista Brasileira de Meteorologia, v. 27, n. 4, p. 423434, 2012.

ARAÚJO JÚNIOR, L. M.; DA SILVA SILVEIRA, C.; DE SOUZA FILHO, F. D. A.; GUIMARÃES, S. O.; PORTO, V. C. análise das projeções de precipitação e temperatura do ipcc-ar5 para os cenários RCP4.5 e RCP8.5 para o século XXI para a Amazônia. 2013

BARATA, M. M. L., CONFALONIERI, U. E. C., LIMA, A. C. L., MARINHO, D. P., LUIGI, G., SIMONE, G. C., SILVA, H. V. Mapa de vulnerabilidade da população do Estado do Rio de Janeiro aos impactos das mudanças climáticas nas áreas social, saúde e ambiente. Rio de Janeiro: Fiocruz. fev.2011.162p.

BESSAT, F. A mudança climática entre ciência, desafios e decisões: olhar geográfico. Terra Livre, v. 1, n. 20, p. 11-26, 2015.

BLAIKIE, P. et al. At risk: natural hazards, people's vulnerability and disasters. Routledge, 2005.

BRASIL. Governo Federal. Plano de Desenvolvimento Territorial Sustentável do Arquipélago do Marajó. 2007. 313p. Disponível em http ://bvsms. saude.gov.br/bvs/ publicações/plano_desenv_arquipelago_marajo.pdf. Acesso em: 27 maio 2020.

CEPED, Centro de Estudos e Pesquisas em Engenharia e defesa civil. Atlas Brasileiro de Desastres naturais. Santa Catarina. Acesso http:/www.ceped.ufsc.br/atlas-brasileiro-de-desastres-naturais-1991-a-2012 em 31 de agosto 2019.

CHOU, S. C.; LYRA, A.; MOURÃO, C.; DERECZYNSKI, C.; PILOTTO, I., GOMES, J.; CAMPOS, D. Assessment of climate change over South America under RCP 4.5 and 8.5 downscaling scenarios. American Journal of Climate Change, v.3, n.05, p. 512, 2014.

CONFALONIERI, U. E. C. Variabilidade climática, vulnerabilidade social e saúde no Brasil, Terra livre, v. 1, n. 20, p. 193-204, 2015.

CONFALONIERI, U.E.C. et al. Modelo Conceitual para Avaliação Municipal da Vulnerabilidade Humana à Mudança do Clima no Brasil: Contribuição da Fiocruz ao Plano Nacional de Adaptação. Sumário Metodológico. Belo Horizonte 2016. 28p. Disponível em: http://www.sisvuclima. com.br/sobre/. Acesso em 25 de maio de 2020.

CONTI, J. B. Considerações sobre as mudanças climáticas globais. Revista do Departamento de Geografia, v. 16, p. 70-75, 2005. 
COSTA, C. P. W.; DE SOUZA, E. B.; ALVES, L. M.; MEIRA FILHO, L. G.; DA SILVA FERREIRA, D. B.; KUHN, P. A. F.; SODRÉ, G. R. C. Avaliação de simulação histórica da precipitação e temperatura na Amazônia oriental utilizando um modelo de alta resolução. Revista Brasileira de Climatologia, v. 25, 2019.

CPTEC. Centro de Previsão de Tempo e Estudos Climáticos. Cenários Climáticos. Acesso: https://projeta.cptec.inpe.br/\#/dashboard em 10 agosto 2019.

CRISPIM, D. L., RODRIGUES, R. S. S., DE ABREU VIEIRA, A. S., DE OLIVEIRA SILVEIRA, R. N. P., FERNANDES, L. L. Espacialização da cobertura do serviço de saneamento básico e do índice de desenvolvimento humano dos municípios do Marajó, Pará. Revista Verde de Agroecologia e Desenvolvimento Sustentável, v.11, n.4, p. 112-122, 2016.

DANTAS, M. E., SHINZATO, E., BRANDÃO, R. D. L., FREITAS, L. C. B., TEIXEIRA, W. G. Origem das paisagens. Embrapa Solos-Capítulo em livro científico (ALICE). 2014.

DARELA FILHO, J. P., LAPOLA, D. M., TORRES, R. R., LEMOS, M. C. Socio-climatic hotspots in Brazil: how do changes driven by the new set of IPCC climatic projections affect their relevance for policy?. Climatic change, v. 136, n.3-4, p.413-425, 2016.

DEBORTOLI, N. S., CAMARINHA, P. I. M., MARENGO, J. A., RODRIGUES, R. R. An index of Brazil's vulnerability to expected increases in natural flash flooding and landslide disasters in the context of climate change. Natural hazards, v.86, n.2, p.557-582, 2017.

ESPIRITO-SANTO, C. M.; SZLAFSZTEIN, C. F. Gestão de risco de desastres em planos diretores de três municípios da zona costeira do estado do Pará, Brasil. Revista de Gestão Costeira Integrada, v. 16, n. 2, p. 223-229, 2016.

FIOCRUZ. Fundação Oswaldo Cruz. Manual Sistema de Vulnerabilidade Climática, Sisvuclima. Rio de Janeiro, Brasil, 2016. Acessado http://www.sisvuclima.com.br/ em 25/10/2019.

FREITAS, M. I. C; CUNHA, L. Cartografia da vulnerabilidade socioambiental: convergências e divergências a partir de algumas experiências em Portugal e no Brasil. Revista Brasileira de Gestão Urbana, p. 15-31, 2013.

GUPTA, A. K.; NEGI, M.; NANDY, S.; KUMAR, M.; SINGH, V.; VALENTE, D.;PANDEY, R. Mapping socio-environmental vulnerability to climate change in different altitude zones in the Indian Himalayas. Ecological Indicators, v.109, p.105787, 2020.

IBGE - Instituto Brasileiro De Geografia e Estatística. Manual Técnico de Geomorfologia. 2. ed., Rio de Janeiro, 175 p. 2009.

IBGE - Instituto Brasileiro De Geografia e Estatística. Manual Técnico da Vegetação Brasileira. 2. ed., Rio de Janeiro, 271 p. 2012.

IBGE - Instituto Brasileiro de Geografia e Estatística. Estimativas populacionais dos municípios. Disponível https://cidades.ibge.gov.br/. Acesso em 29 de novembro de 2019. 
IDHM - Índice de Desenvolvimento Humano municipal. Disponível em https://www.firjan.com. br/ifdm/. Acessado em 05/03/2019

IPCC - Intergovernmental Panel on Climate Change. "Intergovernmental Panel on Climate Change," in Climate Change 2014: Synthesis Report. Contribution of Working Groups I, II and III to the Fifth Assessment Report of the Intergovernmental Panel on Climate Change, R. K. Pachauri and L. A. Meyer, Eds., IPCC, Geneva, Switzerland, 2014, https://www.ipcc.ch/ report/ ar5/syr/, 2014.

IWAMA, A. Y.; BATISTELLA, M.; FERREIRA, L. D. C. Riscos geotécnicos e vulnerabilidade social em zonas costeiras: desigualdades e mudanças climáticas. Ambiente $\mathbb{\&}$ Sociedade, v.17, n.4, p.251-274, 2014.

LIMA, J.; MOYSÉS, A. (Org.). Como andam Belém e Goiânia. Rio de Janeiro: Letra Capital: Observatório das Metrópoles, v. 11, 2009.

LEAL FILHO, W., MODESTO, F., NAGY, G. J., SAROAR, M., YANNICKTOAMUKUM, N., HA'APIO, M. Fostering coastal resilience to climate change vulnerability in Bangladesh, Brazil, Cameroon and Uruguay: a cross-country comparison. Mitigation and adaptation strategies for global change, v.23, n.4, p.579-602, 2018.

MAIOR, M. M. S.; CÂNDIDO, G. A. Avaliação das metodologias brasileiras de vulnerabilidade socioambiental como decorrência da problemática urbana no Brasil. Caderno Metropolitano, v. 16, n. 31, p. 241-264, 2014.

MAVROMATIDI, A., BRICHE, E., CLAEYS, C. Mapping and analyzing socio-environmental vulnerability to coastal hazards induced by climate change: An application to coastal Mediterranean cities in France. Cities, v. 72, p.189-200, 2018.

MAPBIOMAS. Mapeamento Anual da Cobertura e Uso do Solo do Brasil. Disponível em: https://mapbiomas.org/estatisticas. Acesso em 25 de março de 2019.

MENEZES, J. A., CONFALONIERI, U., MADUREIRA, A. P., DUVAL, I. D. B., SANTOS, R. B. D., MARGONARI, C. Mapping human vulnerability to climate change in the Brazilian Amazon: the construction of a municipal vulnerability index. PloS one, v.13, n.2, 2018.

MMA, Ministério do Meio Ambiente. Municípios costeiros do Estado do Pará. Disponível em https:/www.mma.gov.br/informma/item/10592-lista-munic\%C3\%ADpios-da-zona-costeira. html Acesso em: 20 janeiro 2020.

NEVES, C. F.; MUEHE, D. Vulnerabilidade, impactos e adaptação a mudanças do clima: a zona costeira. Parcerias estratégicas, v. 13, n. 27, p. 217-296, 2010.

NOBRE, C. A.; SAMPAIO, G.; SALAZAR, L. Mudanças climáticas e Amazônia. Ciência e Cultura, v. 59, n. 3, p. 22-27, 2007.

O'BRIEN, K. A. R. E. N., ERIKSEN, S., NYGAARD, L. P., SCHJOLDEN, A. N. E. Why different interpretations of vulnerability matter in climate change discourses. Climate policy, v.7, n.1, p. 
OJIMA, R.; MARANDOLA JR, E. Mudanças climáticas e as cidades: novos e antigos debates na busca da sustentabilidade urbana e social. Editora Blucher, 2013.

PBMC, Politica Brasileira de Mudanças Climática. Impacto, vulnerabilidade e adaptação das cidades costeiras brasileiras às mudanças climáticas: Relatório Especial do Painel Brasileiro de Mudanças Climáticas [Marengo, J.A., Scarano, F.R. (Eds.)]. PBMC, COPPE - UFRJ. Rio de Janeiro, Brasil. 184 p. ISBN: 978-85-285-0345-6, 2016.

PEREIRA, F. S.; VIEIRA, I. C. G. Expansão urbana da Região Metropolitana de Belém sob a ótica de um sistema de índices de sustentabilidade. Revista Ambiente \& Água, v. 11, n. 3, p. 731-744, 2016.

PEREIRA, L. C. C. DIAS, J. A., DO CARMO, J. A., POLETTE, M. A zona costeira amazônica brasileira. Revista de Gestão Costeira Integrada-Journal of Integrated Coastal Zone Management, v. 9, n. 2, p. 3-7, 2009.

PNUD. Programa das Nações Unidas para o Desenvolvimento. Atlas do Desenvolvimento Humano no Brasil. Acesso PNUD https:/www.br.undp.org/content/brazil/pt/home/idh0/rankings/ idhm-municipios-2010 em 20/11/2019.

QUINTÃO, A. F.; BRITO, I.; OLIVEIRA, F; MADUREIRA, A. P; CONFALONIERI, U. Social, Environmental, and Health Vulnerability to Climate Change: The Case of the Municipalities of Minas Gerais, Brazil. Journal of environmental and public health, 2017.

RIBEIRO, W. C. Impactos das mudanças climáticas em cidades no Brasil. Parcerias estratégicas, v. 13, n. 27, p. 297-322, 2010.

RODRIGUES, J. C.; CASTRO, E. M. R. Companhia Docas do Pará (CDP): plataforma logística do capital internacional na Amazônia Oriental. Contribuciones a las Ciencias Sociales, v.20, p.1-14, 2013.

SANTOS, M. R., VITORINO, M. I., DA SILVA PIMENTEL, M. A. Vulnerabilidade e mudanças climáticas: análise socioambiental em uma mesorregião da Amazônia. Revista Ambiente $\mathbb{E}$ Água, v.12, n.5, p. p. 842-854, 2017.

SANTOS, R. B. D., MENEZES, J. A., CONFALONIERI, U., MADUREIRA, A. P., DUVAL, I. D. B., GARCIA, P. P., MARGONARI, C. Construção e aplicação de um índice de vulnerabilidade humana à mudança do clima para o contexto brasileiro: a experiência do estado do Espírito Santo. Saúde e Sociedade, v. 28, p. 299-321, 2019.

SCHUMANN, L. R. M. A.; MOURA, L. B. A. Índices sintéticos de vulnerabilidade: uma revisão integrativa de literatura. Ciência \& Saúde Coletiva, v.20, p.2105-2120, 2015.

SILVA SANTOS, M. R. VITORINO, M. I., BRAGA, C. C., DE OLIVEIRA SOUTO, J. I., DO NASCIMENTO MOURA, M., JÚNIOR, P. P. F. Padrões de precipitação mensal na mesorregião metropolitana de Belém: uso do CMORPH e componentes principais. Revista Brasileira de 
Geografia Física, v.9, n.7. p,2301-2311, 2016.

SILVA, D. F.; DA COSTA, G. G. G.; LOPES, M. D. S. B.; LOPES, D. F.; DE OLIVEIRA CUNHA, M. V. P. Análise da relação entre esgotamento sanitário, idh e mortalidade infantil no estado do Pará. Caderno de Pesquisa, Ciência e Inovação, p. 23, 2018.

SOUZA FILHO, P. Impactos naturais e antrópicos na planície costeira de Bragança (NE do Pará). Ecossistemas Costeiros, Impactos e gestão ambiental. MPEG, Belém, p. 113-125, 2001.

SOUZA, E. B., DA SILVA FERREIRA, D. B., GUIMARÃES, J. T. F., DOS SANTOS FRANCO, V., DE AZEVEDO, F. T. M., DE MORAES, B. C. (2017). Padrões climatológicos e tendências da precipitação nos regimes chuvoso e seco da Amazônia oriental. Revista Brasileira de Climatologia, v. 21, p. $81-93,2017$.

SOUZA, L.S.B.; ROSSETTI, D.F.; ELIS, W.R. Sondagem elétrica vertical na ilha de Marajó. Em: Simp. de Geol. Amaz., 9, Manaus. CD-ROM: Questões técnicas e científicas (geofísica, sensoriamento remoto / SIG). (Em português), 2009.

SZLAFSZTEIN, C. F. Vulnerability and response measures to natural hazard and sea level rise impacts: long-term coastal zone management, NE of the State of Pará, Brazil. Tese de Doutorado. Christian-Albrechts Universität Kiel. 2003.

SZLAFSZTEIN, C.; STERR, H. A GIS-based vulnerability assessment of coastal natural hazard, state of Pará, Brazil. Journal of Coastal Conservation. v.11, n.1, p, 53-66, 2007.

SZLAFSZTEIN, C.; STERR, H. Coastal zone management tool: a GIS-based vulnerability assessment to natural hazards. In: Saint Paul, U.; Schneider, H. (Orgs.), Mangrove dynamics and management in North Brazil, Berlin: Springer-Verlag, Heidelberg, Alemanha. 2010.

TIBÚRCIO, L. H.; CORRÊA, M. D. P. Análise da vulnerabilidade da microrregião de Itajubá por meio do IVG com vistas à mitigação dos impactos causados pelas mudanças climáticas. Ambiente e Sociedade, v. 15, n. 3, p. 123-139, 2012.

VOMMARO, F.; MENEZES, J. A.; DE LIMA BARATA, M. Contributions of municipal vulnerability map of the population of the state of Maranhão (Brazil) to the sustainable development goals. Science of The Total Environment, v. 706, p. 134629, 2020.

WANG, H.; SONG, M. CKmeans.1d.dp: Optimal k-means clustering in one dimension by dynamic programming. The R. Journal, Ohio, v. 3, n. 2, p. 29-33, 2011.

ZANEllA, M. E., OlíMPIO, J. L., COSTA, M. C. L., DANTAS, E. W. C. Vulnerabilidade socioambiental do baixo curso da bacia hidrográfica do Rio Cocó, Fortaleza-CE. Sociedade $\mathbb{\&}$ Natureza, v.25, n.2, p.317-331, 2013.

ZANETTI, V. B., DE SOUSA JUNIOR, W. C., DE FREITAS, D. M. A climate change vulnerability index and case study in a Brazilian coastal city. Sustainability, v.8, n.8, p. 811, 2016. 
Marcos Ronielly da Silva Santos

$\checkmark$ mronielly.mr@gmail.com

ORCiD: https://orcid.org/0000-0002-1959-1424

\section{Maria Isabel Vitorino}

$\checkmark$ vitorino.ufpa@gmail.com

ORCiD: https://orcid.org/0000-0003-3253-5301

\section{Luci Cajueiro Carneiro Pereira}

$\checkmark$ luciccp17@gmail.com

ORCiD: https://orcid.org/0000-0002-3494-3248

\section{Maria Aparecida da Silva Pimentel}

$\checkmark$ mapimentel@ufpa.br

ORCiD: https://orcid.org/0000-0001-9893-9777

\section{Ana Flávia Quintão}

$\varangle$ anaflaviaqf@gmail.com

ORCiD: http://orcid.org/0000-0002-0882-2151
Submitted on: 10/07/2020

Accepted on: 08/03/2021

2021;24e:01671

How to cite: SANTOS, M.R.S.; VITORINO, M.I; PEREIRA, L.C.C.; PIMENTEL, M.A.S.; QUINTÃO, A.F. Socioenvironmental Vulnerability to Climate Change: Conditions of Coastal Municipalities in Pará State. Ambiente $\mathbb{\&}$ Sociedade. São Paulo, v. 24, p. 1-22, 2021. 


\title{
Vulnerabilidade Socioambiental às Mudanças Climáticas: Condições dos Municípios Costeiros no Estado do Pará
}

\author{
Marcos Ronielly da Silva Santos \\ Maria Isabel Vitorino \\ Luci Cajueiro Carneiro Pereira \\ Marcia Aparecida da Silva Pimentel \\ Ana Flávia Quintão
}

São Paulo. Vol. 24, 2021

Artigo Original

\begin{abstract}
Resumo: $\bigcirc$ estudo analisa a vulnerabilidade dos municípios costeiros do estado do Pará, com base na integração de indicadores socioeconômicos, epidemiológicos e climáticos. Os dados foram combinados com os cenários climáticos Representative Concentration Pathway (RCP) 4.5 e 8.5, com base no Índice de Vulnerabilidade Municipal (IVM). Os resultados mostraram que o Índice de Sensibilidade (ISe) e o Índice Sociodemográfico (ISd) apontaram a maior influência na vulnerabilidade atual dos municípios. Quando a vulnerabilidade atual estava relacionada às projeções futuras de mudanças climáticas verificou-se que os municípios mais vulneráveis estão na região da Ilha do Marajó - oeste da área de estudo, onde o IVM varia entre 1 (Afuá) e 0,55 (Soure) para os cenários 4.5 e 8.5 , respectivamente. Acredita -se que estes resultados possam contribuir para a adoção efetivas de políticas públicas, priorizando os municípios mais vulneráveis e preparando-os para lidar com os aspectos adversos das mudanças do clima.
\end{abstract}

Palavras-chave: Clima; Riscos; Socioambiente; Região Costeira; Pará.

Como citar: SANTOS, M.R.S; VITORINO, M.I.V; PEREIRA, L.C.C; ZQUINTÃO, A.F. Socio-environmental Vulnerability to Climate Change: Conditions of Coastal Municipalities in the State of Pará. Ambiente \& Sociedade. São Paulo, v. 24, p. 1-22, 2021.

DOI: http://dx.doi.org/10.1590/1809-4422asoc20200167r1vu2021L3AO 


\title{
Vulnerabilidad Socio-Ambiental al Cambio Climático: Condiciones en Los Municipios Costeros Del Estado de Pará
}

\author{
Marcos Ronielly da Silva Santos \\ Maria Isabel Vitorino \\ Luci Cajueiro Carneiro Pereira \\ Marcia Aparecida da Silva Pimentel \\ Ana Flávia Quintão
}

São Paulo. Vol. 24, 2021

Artículo original
Resumen: Texto do resumo em espanhol. El estudio analiza la vulnerabilidad de los municipios costeros del estado de Pará, a partir de la integración de indicadores socioeconómicos, epidemiológicos y climáticos. Los datos se combinaron con los escenarios climáticos Vía de Concentración Representativa (RCP) 4,5 y 8,5, basados en el Índice de Vulnerabilidad Municipal (IVM). Los resultados mostraron que el Índice de Sensibilidad (ISe) y el Índice Sociodemográfico (ISd) señalaron la mayor influencia en la vulnerabilidad actual de los municipios. Al relacionar la vulnerabilidad actual con las proyecciones futuras de cambio climático se verificó que los municipios más vulnerables se encuentran en la región de la Isla de Marajó - al oeste del área de estudio, donde el IVM varía entre 1 (Afuá) y 0,55 (Soure) para los escenarios 4,5 y 8,5, respectivamente. Se cree que estos resultados pueden contribuir a la adopción efectiva de políticas públicas, priorizando los municipios más vulnerables y preparándolos para hacer frente a los aspectos adversos del cambio climático.

Palabras-clave: Clima; Riesgos; Socioambiente; Región Costera; Pará.

Como citar: SANTOS, M.R.S; VITORINO, M.I; PEREIRA, L.C.C; PIMENTEL, M.A.S; QUINTÂO, A.F. Vulnerabilidad Socio-Ambiental al Cambio Climático: Condiciones en Los Municipios Costeros Del Estado de Pará. Ambiente \& Sociedade. São Paulo, v. 24, p. 1-22, 2021. 